\title{
Negotiating meaning and co-constructing institutionalisable answers. Leadership through gate-keeping in performance appraisal interviews
}

\begin{abstract}
Although the topic of leadership is increasingly becoming an area of interest for discourse analysts, most of the studies on leadership discourse focus on business meetings and largely ignore other institutional contexts. This paper aims to address this gap by exploring leadership discourse in another important but often neglected genre, namely the performance appraisal interview.

Drawing on naturally-occurring performance appraisal interviews recorded in a medical lab, we explore the particularly salient and (from a linguistic perspective) largely under-researched leadership activity of gate-keeping. This leadership activity is central to performance appraisal interviews and evolves around the conjoint negotiation of meaning and the co-construction of institutionalisable answers as they are 'fixed' by means of note taking.

Through an in-depth analysis of how these leadership activities are performed in three performance appraisal interviews, this paper contributes to an understanding of the complex processes through which leadership is actually enacted on the micro-level of interactions in this increasingly relevant genre of institutional discourse.
\end{abstract}

Highlights: (http://www.elsevier.com/wps/find/authorsview.authors/highlights)

- We study leadership discourse in performance appraisal interviews.

- We explore the leadership activity of gate-keeping.

- We identify and describe some discursive resources through which leadership is done.

- Findings show that leadership is a collaborative activity rather than an attribute.

Keywords: leadership, gate-keeping, performance appraisal interviews, meaning negotiation, institutionalisability of answers

\section{Introduction}

Although the topic of leadership is increasingly becoming an area of interest for discourse analysts (e.g. Choi and Schnurr, 2014; Clifton, 2006; Svennevig, 2012), most of the studies on leadership discourse focus on business meetings and largely ignore other institutional contexts. This paper aims 
to address this gap by exploring leadership discourse in an increasingly important but largely underresearched genre, namely the performance appraisal interview.

Performance appraisal interviews have been defined as "recurrent strategic interviews between a superior in an organization and an employee that focus on employee performance and development" (Asmuß, 2008: 409). This genre has been largely under-researched from a discursive perspective, since most studies tend to "focus on 'before' and 'after' the performance appraisal interview" (Asmuß, 2008: 410) instead of analyzing the interactional aspects of how these interviews are actually conducted. As a consequence, these interviews have "remained a black box around which numerous theories and quasi-theories of interaction have emerged" (Clifton, 2012a: 284).

This dearth of research on performance appraisal interviews is surprising for two reasons. First, from an analytical perspective, and as the rare discursively oriented studies on performance appraisal interviews have demonstrated, there are a number of interesting activities to be analyzed on a turn by turn basis in these interviews. For example, Asmuß (2008) focuses on the - often framed as socially problematic - activity of negatively assessing employees. She approaches this topic from a conversation analytic perspective by applying the notion of preference and by discussing the interactional consequences of using either preferred or dispreferred turn shapes in these negative assessments. Using the same methodological perspective, Clifton (2012a) looks into the way in which face-threatening activities are often very carefully dealt with in performance appraisal interviews in order to prevent any attacks on the identities constructed by the appraiser and appraisee and to maintain a good working relationship. In line with Asmuß's findings, Clifton emphasizes the collaborative nature of facework in performance appraisal interviews, describing it as a "joint accomplishment" (Clifton, 2012a: 302).

Second, from an organizational point of view, performance appraisal interviews have gained more and more importance. This is because of their orientation towards the evaluation of employees, which is an essential element in the process of employee development. As such, these interviews are "critical to the effective use of human capital, and, ultimately, to the survival of any organization" (Clifton, 2012a: 283). Moreover, there has been a growing awareness of this, "as institutions and organizations now invest more and more resources in evaluating employee performance" (Asmuß, 2008: 408) and consequently, performance appraisal interviews have secured their position as a crucial aspect of internal organizational communication.

Moreover, due to their relevance in many institutional contexts, it is worth investigating appraisal interviews as sites of leadership performance - in particular due to the fact that a range of gatekeeping activities occur when transforming these performance appraisal interactions into written reports, as we will discuss below in more detail.

Although leadership has always been a topic that has drawn a lot of attention to it and that has been researched intensively across different disciplines, it is only recently that this research has taken "a discursive turn". Over the last decade or so, researchers have increasingly recognized the crucial role that discourse plays for the enactment and construction of leadership (see e.g. the contributions in Tourish and Jackson, 2008) and have started to acknowledge the various benefits that discourse analytical approaches may add to the study of leadership (e.g. Clifton, 2006; Fairhurst, 2007; Tourish 
and Jackson, 2008). And although there is little agreement among scholars as to what exactly leadership is, more recent approaches conceptualize leadership as a performance or an activity rather than viewing it as specific "traits, behaviors, influence, interaction patterns, role relationships, and occupation of an administrative position" (Heifertz, 1998; Hosking, 1997; Northouse, 1997; Yukl, 2002: 3).

Acknowledging the central role of discourse in performing the various leadership processes, then, researchers are increasingly shifting their focus towards exploring how leadership is actually done on the micro-level of interaction (e.g. Asmuß, 2009; Baxter, 2010; Clifton, 2006; Holmes, 2005, 2006; Holmes et al., 2011; Marra et al., 2006; Schnurr, 2009a, 2009b; Schnurr and Chan, 2009). Thus, rather than trying to develop "grand theories of leadership", they hope to achieve "a better understanding of the everyday practices of talk that constitute leadership and a deeper knowledge of how leaders use language to craft 'reality'" and to construct meaning (Clifton, 2006: 203).

However, although leadership is increasingly becoming a topic of research interest from a discourse analytical perspective, most of this research focuses on business meetings and explores various aspects of how leadership is performed in meeting talk (e.g. Angouri and Marra, 2011; Baxter, 2010; Clifton, 2006, 2012b; Rogerson-Revell, 2011; Schnurr and Chan, 2011; Schnurr and Zayts, 2011; Svennevig, 2011). This focus on meetings is perhaps not surprising given that meetings form an integral and often crucial aspect of many (especially white-collar) workplace realities. They have even been described as "the very stuff of 'work"' (Holmes and Stubbe, 2003: 56). And indeed, by examining leadership discourse in the context of meetings, several activities through which leadership is actually done have been identified, such as opening and closing meetings, summarizing progress, negotiating agreement and reaching consensus, and overcoming disagreement and conflict (Angouri and Marra, 2011; Choi and Schnurr, 2014; Holmes, 2000; Schnurr and Chan, 2011; Svennevig, 2011). While we acknowledge the central role of meetings in the workplace (see e.g. Angouri and Marra, 2011: 85), and thus their importance as a site for investigating leadership discourse, this overwhelming focus of previous research on meetings means that other, potentially equally interesting contexts in which leadership is performed have often been overlooked. This paper addresses this issue by exploring how leadership is done in performance appraisal interviews.

Although performance appraisal interviews typically include the enactment of various leadership activities, we focus here on the particularly salient and (from a linguistic perspective) largely underresearched activity of gate-keeping. Gate-keeping has been identified as an important leadership activity (Holmes, 2007) because it is closely related to the construction of institutionally acceptable meaning and the creation of an institutionally acceptable reality. As Clifton (2012b: 150) maintains, "leadership is regarded as influencing the process of managing meaning so that certain organizational meanings are privileged over others" (see also Nielsen, 2009; Smircich and Morgan, 1982). This, on the one hand, contributes to creating a particular organizational reality (or realities) in which an interaction takes place and it, on the other hand, also reflects, as well as shapes and reinforces (or challenges) the organizational norms and expectations that characterize that reality. Nielsen (2009: 23), for example, shows how middle managers regularly "interpret experiences and observations of employees and relate them to organizational contexts, practices, and strategies." She interprets this as a crucial leadership behavior as it contributes to "contextualizing employee perceptions in accordance with executive-level perceptions of organizational practices." (Nielsen, 
2009: 23). Although these processes of meaning construction and reality creation seem to regularly occur in everyday workplace interactions, they are particularly salient and relevant in the context of performance appraisal interviews where the interviewer is responsible for ensuring that the interviewee's answers (to the various prescribed questions) are institutionalisable in that they reflect institutional practices, assumptions and values. This institutionalisability of answers is reflected in two aspects: on the one hand, it refers to the match between the interviewee's answers and the institution's goals and values; and on the other hand, it also refers to the process of talking the organization into being through the collaborative moulding of these answers in institutionalisable terms (see Boden, 1994; Smircich and Morgan, 1982). In these performance appraisal interviews the interviewer thus takes on a leadership role by acting as a gatekeeper "within the organization" (cf Holmes, 2007: 1995). In this case, this means that in the course of transforming the conversations of the performance appraisal interviews into written reports, the leader selects certain aspects of the interaction for the production of this text.

Interestingly, in the field of organizational communication research, texts are regarded as essential in the achievement of authority (Benoit-Barné and Cooren, 2009: 26), viewing them as not only reporting on what occurred in the course of an interaction, but actually constituting organizational reality (Taylor, 2011: 1281). Crucially, a text is thus not "a neutral discription of reality", but rather "it authorizes the activities and projects of some people and communities, while downgrading those of others" (Taylor, 2011: 1283). While this may initially be obvious to the readers of the text, for example to the appraisee of such a performance appraisal interview, gradually a process of distanciation takes place, removing texts further and further from their initial contexts. This results in an increasing ambiguity "until all that remains is an abstract representation of the original interactions" from which individual authors have vanished and which now conveys a collective authority (Koschmann, 2013: 66-67). So texts are seen as fixing organizational reality in a way that talk cannot, and so this transfer from spoken to written form is essential to leadership and the management of meaning. In particular, as the writer of the report of a performance appraisal interview, the appraiser, is in the powerful gate-keeping position of solidifying conversations into texts (Koschmann, 2013: 66) and this text will then gain authority through the distanciation that occurs because of its written form.

This paper aims at exploring some of the processes through which these leadership activities are enacted on the micro-level of interaction in the genre of performance appraisal interviews, and to identify and describe some of the discursive resources that interlocutors draw on when performing these gate-keeping activities in this specific institutional context. In particular, we zoom in on how the gate-keeping activity of selecting and putting information down on paper in the form of notes which will form the basis of the report - is negotiated in the course of the interview. Since we did not have access to the notes nor the reports themselves, these are not discussed here, but we focus on the discursive means that are used in this process of doing formulation "as a tool for "fixing" meaning" (Clifton, 2006: 214, quotation marks in the original) in the creation of organization reality in the course of the discussion and its subsequent note taking.

\section{Data}


The data we are using are taken from a larger corpus of spoken institutional interactions in Dutch, which contains, among other data types, ten performance appraisal interviews. These were collected in two different institutions, namely a medical lab and an engineering company. The data we are focusing on here come from the former data collection site and they were taped in the winter (December - January) of 2010/2011 in a medical lab that is situated on the border between the Netherlands, Belgium and Germany ${ }^{1}$. Given the sensitivity of some of the topics under discussion and the often fairly face-threatening nature of such performance appraisal interviews in which employees' professional activities are evaluated and in which negative evaluations potentially have implications for their career development, we only got permission to make audiotapes. Although we are aware of this limitation of the data (especially since recent research has underlined the fact that such face-to-face interactions are multimodal achievements (see e.g. Svennevig, 2012)), we have tried to minimise this by integrating another important aspect of multimodal interaction into our analysis, namely the interaction between the turn-by-turn construction of these interviews and the pre-formulated written documents (see also Svennevig, 2012: 8), which in this case consist of a questionnaire that is essential in the performance appraisal process in the institution where our data were collected. Also, an ethnographic interview with the supervisor was carried out, in which the whole performance appraisal process was discussed and previous problems were probed for. This mainly helped us to understand the way in which the organization dealt with the issue of employee development and how this was institutionalized in the organization.

On the basis of this information we collected in addition to the interview data themselves, we can now describe how this process takes place in the organisation under study. First of all, performance appraisal interviews are organised on a yearly basis and are strongly guided by the questionnaire, which determines the topical discussion of the interview itself. In general, this discussion is based on four competencies which the organization has defined as essential, including self-development and customer-orientedness. These basic competencies are divided into 23 subcompetencies as mentioned in the questionnaire, including creativity, flexibility and patients' issues. All these competencies are then translated into a list of specific topics and questions which is adapted to each specific employee. This list is sent to all employees prior to the interview, and they are asked to prepare answers to these questions and send them back to the supervisor before the interview takes place.

During the interview, this questionnaire is used as an agenda which structures the discussion (for a more detailed discussion, see Van De Mieroop and Vrolix, 2014). After the interviews, the supervisor writes a report on the basis of the notes she took during the interaction, which is then sent back to the employees who can request further adjustments to this report. In the ethnographic interview, the supervisor told us that there have never been any discussions on the basis of these reports. The reports are then filed and picked up again the next year as a basis for the following performance appraisal interview. They are never directly used in any other way in the organization: when there are opportunities for promotion, these are always openly communicated to all the employees and result in official vacancies for which all employees can apply, so these reports do not have a direct impact on that. However, in case of unsatisfactory performance, the reports of previous performance appraisal interviews may be used as additional documentation in an extensive file that could possibly lead to the suspension or the discharge of an employee; but again the reports are not directly

\footnotetext{
${ }^{1}$ We are largely endebted to Eveline Vrolix for collecting and providing an initial transcription of the data.
} 
consequential in these situations either. In spite of this, the reports are important in an indirect way, because through the written record of the preceding performance appraisal interview, previous behaviour of the employee is captured on paper and, in the case of negative evaluations, this can have consequences for the way the tasks are divided among employees, which in turn may stimulate or hinder an employee's career opportunities. So in an indirect way, the reports influence the employees' professional development.

\section{Analysis}

In these performance interviews interlocutors draw on a myriad of strategies to negotiate meaning and to do leadership. We focus here on one specific leadership activity which is particularly relevant in this context, namely gate-keeping (Holmes, 2007). In the performance appraisal interviews that we have collected, one of the processes through which gate-keeping is enacted is finding an institutionalisable answer to a range of set questions that characterize this specific genre of organizational communication. The institutionalisability of the answer depends on the extent to which the supervisor selects, reformulates and negotiates this when taking her notes. These notes, in turn, form the basis for the report that is essential for the construction of organizational reality, especially because of its written form (see e.g. Taylor, 2011).

In what follows we discuss in detail three specific discursive strategies which are frequently used by the participants in our data to achieve this, namely (1) rephrasing the interviewee's words in institutional terms, (2) dealing with the interviewee's challenges of institutional norms and practices, and (3) institutionalizing the interviewee's words. These processes, however, are not always clearly distinguishable from each other and there is some overlap. For example, as we show below, when rephrasing the interviewee's words in institutional terms the interviewer may at the same time encourage the interviewee to ratify this institutionalisation. We have chosen five representative examples taken from three performance appraisal interviews to illustrate how these leadership activities are enacted on the micro-level of interaction.

For ease of reading, we decided to work on fragments in which the same topic is being discussed, namely patients' issues. This topic is a subtopic of the overarching theme of customer-orientedness, which was introduced right at the start of the interview. So the subtopic of patient's issues is discussed very early in the interviews (at about four minutes (on average) after the start of the interview) and it is formulated in the questionnaire by means of the following two related questions:

1. In what way does your involvement in patients' issues show itself?

\section{How could you further increase that?}

The first question is oriented at the current situation, while the second question probes for room for improvement in the future.

In the three interviews that we discuss below, the discussion developed in a relatively similar way since all interviewees responded negatively to the second question thereby making it potentially challenging to obtain an institutionalisable answer. This negative attitude of employees towards further improving their performance, in turn, makes these interviews particularly interesting from a leadership perspective as we would expect interlocutors to invest some discursive efforts into 
negotiating their divergent views: the interviewee's resistance to the organization's expectations on the one hand, and the interviewer's role as a gate-keeper and thus reinforcer of organizational norms and expectations on the other hand. In our analyses below we explore how leadership is done in these instances by means of gate-keeping, and more specifically, (1) how it is talked into being on a turn-by-turn basis throughout the interaction in constant negotiation between the interviewer and the interviewee; and (2) how it becomes tangible in the negotiation of the notes that form the basis of the report, which will solidify the conversation into text, in which certain interpretations and answers are authorized, while others are downgraded (Koschmann, 2013; Taylor, 2011).

\section{Rephrasing the interviewee's words in institutional terms}

This extract shows a relatively short sequence in which after the discussion of the topic, the interviewer (IR) arrives at an institutionalisable answer by slightly, but purposefully, rephrasing the interviewee's (IE) contributions.

Example 1 - Interview 1

IE answers a question about how her involvement in patients' issues is shown and how it could be further improved. IR then summarizes IE's various points by referring to what she has written down thereby institutionalizing IE's answer.

\begin{tabular}{|c|c|c|}
\hline 1 & \multirow{4}{*}{$I R$} & Maar de on één na euh derdelaatste $\uparrow v r a a a$ \\
\hline 2 & & Op welke manier blijkt jouw betrokkenheid bij de \\
\hline 3 & & patiëntenproblema个tiek? \\
\hline 4 & & (1.1) \\
\hline 5 & \multirow[t]{2}{*}{ IR } & En hoe zous se die kennen vergroten nog? \\
\hline 6 & & (3.5) \\
\hline 7 & \multirow[t]{2}{*}{$I E$} & Nou das eigenlijk weer het $\uparrow$ zelfde denk ich. Ich heb \\
\hline 8 & & hie zo (nu en dan) de bereidheid om langer te wer $\uparrow$ ken= \\
\hline 9 & IR & $=M m m$. \\
\hline 10 & \multirow[t]{3}{*}{$I E$} & zorgverme-vuldig proberen om te gaan en te handelen \\
\hline 11 & & in het belang van de pa个tiënt. \\
\hline 12 & & $(1.6)$ \\
\hline 13 & \multirow[t]{3}{*}{$I E$} & En op andere werkplekken, helpen, ze de telefoon \\
\hline 14 & & aannummen, prikken, de ( ) op dien dings \\
\hline 15 & & geblieven en doa e[u:h. \\
\hline 16 & \multicolumn{2}{|c|}{$I R \quad[\mathrm{~mm}$} \\
\hline \multicolumn{3}{|c|}{ (ves an example of one of her tasks)) } \\
\hline 25 & & (7.5) \\
\hline 26 & \multirow[t]{3}{*}{ IR } & Euhm >wat ich (ook nog) he opschrijven<, \\
\hline 27 & & indien nodig de bereidheid uh langer te werken, \\
\hline 28 & & flexibiliteit met betrekking tot hulp aan andere (.) anderen $\uparrow$ hè \\
\hline 29 & IE & Uhu. \\
\hline 30 & $I R$ & ) resultaten voor ( $)^{\circ}$ \\
\hline 31 & & (2.5) \\
\hline 32 & $I E$ & Ja zo-euh zorgvuldig proberen:euh te werken gewoon [hè. \\
\hline 33 & $I R$ & 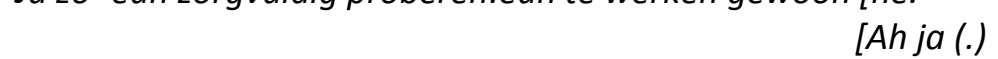 \\
\hline 34 & & $>j a j a$ \\
\hline 35 & & (2.4) \\
\hline
\end{tabular}




\begin{tabular}{|c|c|c|}
\hline \multirow{2}{*}{\multicolumn{3}{|c|}{ But the one but erm third final $\uparrow$ question. }} \\
\hline & \multirow[t]{4}{*}{$\mathrm{IR}$} & \\
\hline 2 & & \\
\hline 3 & & $\begin{array}{l}\text { In what way does your involvement in patients' } \\
\text { iss 个ues show itself? }\end{array}$ \\
\hline 4 & & (1.1) \\
\hline 5 & IR & \multirow{2}{*}{ And how could you further increase that? } \\
\hline 6 & & \\
\hline 7 & IE & \multirow{2}{*}{$\begin{array}{l}\text { Well that is actually again the } \uparrow \text { same I think. I have } \\
\text { here so (now and then) the willingness to work long } \uparrow \text { er= }\end{array}$} \\
\hline 8 & & \\
\hline 9 & IR & $=\mathrm{Mmm}$. \\
\hline 10 & IE & caremulti- fully try to deal with and to act \\
\hline 11 & & in the interest of the $\uparrow$ patient. \\
\hline 12 & & $(1.6)$ \\
\hline 13 & IE & And at other workplaces, helping, picking up the \\
\hline 14 & & \multirow{2}{*}{$\begin{array}{l}\text { telephone, pricking, the ( } \\
\text { and there e:[rm }\end{array}$} \\
\hline 15 & & \\
\hline 16 & $\begin{array}{l}\mathrm{IR} \\
\text { ample of one of her tasks)! }\end{array}$ & {$[\mathrm{mm}$} \\
\hline ((IE gives a & $a m p$ & f one of her tasks)) \\
\hline 25 & & (7.5) \\
\hline 26 & $\mathrm{IR}$ & \multirow{3}{*}{$\begin{array}{l}\text { Erm > what I have (also still) written down<, } \\
\text { if necessary the willingness to uh work longer, } \\
\text { flexibility with regard to help to other (.) others } \uparrow \text { hèy }\end{array}$} \\
\hline 27 & & \\
\hline 28 & & \\
\hline 29 & $\mathrm{IE}$ & Uhu. \\
\hline 30 & $\mathrm{IR}$ & And also still ${ }^{\circ}(\quad)$ results for ()$^{\circ}$ \\
\hline 31 & & $(2.5)$ \\
\hline 32 & $\mathrm{IE}$ & Yes ca- erm try to:erm work carefully simply [hèy. \\
\hline 33 & $\mathrm{IR}$ & [Ah yes (.) \\
\hline 34 & & $\begin{array}{l}>\text { yes yes.< } \\
(2.4)\end{array}$ \\
\hline 35 & & $(2.4)$ \\
\hline
\end{tabular}

The topic of patients' issues is first initiated by the interviewer in lines 1-5, then conjointly discussed in lines 7-24 and finally recorded in the notes of the interviewer (lines 26-34). In lines 7-16, the discussion which forms the basis of this note taking is taking place. Interestingly, in recounting her own contributions to the involvement in patients' issues, the interviewee uses an impersonal perspective which presents a description of how this topic is put into practice in the lab in rather general terms. The interviewer implicitly invites the interviewee to elaborate on this topic, as the continuers (line 9 and 16) and the pause (line 12) encourage her to keep the floor. The interviewer thereby encourages collaborative construction of meaning. This behavior has been ascribed to leadership in the past (Smircich and Morgan, 1982), and particularly in the case of performance appraisal interviews in which the interviewees' active participation is described as an important challenge (Asmuß, 2008: 411), the interviewer's encouraging behavior can be viewed as a leadership activity.

After a lengthy pause, the interviewer then follows up on the interviewee's account in line 26 and begins reading out the notes that she has been taking. In spite of a lack of videodata, this is clear because the interviewer explicitly frames the rest of the turn as based on what she 'has written down' (line 26), thus switching to a mode in which an attempt is made to capture and categorize the messiness of conversational reality into an institutionally acceptable format. At this point in the interaction there is a codeswitch to standard Dutch (lines 27-28), which we argue is due to both the 
interviewer's reading mode and the fact that this reading out loud of her notes marks the transformation of the prior talk into an institutionalized outcome, namely the notes that will eventually lead to the interviewer's performance appraisal report. More importantly though, in this process of institutionalizing the prior talk, the interviewer has partially reformulated the interviewee's answer: first of all, she almost literally reproduces the interviewee's previous contributions (e.g. line 8 in comparison with line 27). Furthermore, the interviewer rephrases the interviewee's original temporal mitigation nu en dan ('now and then', line 8) into a more causally oriented mitigation indien nodig ('if necessary', line 27). This substitutes the random nature of the interviewee's willingness to work longer hours with a more purposeful approach which is in line with the institutional agenda. Secondly, the second part of the interviewee's answer is reformulated into a more abstract description that more explicitly integrates one of the institution's subcompetencies, namely flexibility. Furthermore, the nominalization hulp ('help', line 28), formal word collocation met betrekking tot ('with regard to', line 28) and vagueness andere anderen ('other others', line 28) all contribute to an impersonal, and thus also more institutional style. The interviewer ends her discussion with the tag hè ('hey', line 28), of which the rising intonation possibly invites the interviewee to take the floor. After the interviewee voices an acknowledgment token (uhu, line 29), the interviewer once more explicitly orients her contribution towards one of the institution's competencies (namely result-orientedness) while reformulating the interviewee's words into a written form, thus 'fixing' the organizational reality.

So while allowing the interviewee to produce her own formulations, at the same time the interviewer acts as a gate-keeper whose aim is to ensure the institutional goals of this performance appraisal interview are being met. She achieves this, for example, by rephrasing some of the interviewee's wording (e.g. 'if necessary' in line 27) and by reformulating some of her contributions into institutional jargon which is specifically linked to the competencies of the organization (e.g. lines 27-28 and 30). Through these processes, then, the interviewer steers the conversation towards achieving an institutionalisable answer, which also to some extent involves explicitly projecting institutionalisable wordings upon the interviewee. Through these processes of constructing meaning, the interviewer at the same time actively contributes to creating a certain organizational reality, which is another behavior that is described as a leadership activity (Enderle, 1987; Nielsen, 2009; Smircich and Morgan, 1982).

It is important to note that the interviewee ratifies the interviewer's reformulations implicitly by means of minimal feedback (line 29) and explicitly by the affirmative particle in line 32 (ja, 'yes'). Following this, the interviewee partially repeats one of the elements she previously mentioned (see line 10) in a mitigated form (c.f. the gewoon, 'simply'), which in turn is then ratified by the interviewer who treats it as an addition, as the repeated affirmative particles indicate. After a further short exchange (not shown here), the interviewer closes this topic and moves on to the next question.

This extract thus nicely shows how the interviewer rephrases the interviewee's words in institutional terms. More specifically, on the one hand she ensures that they are formulated in a suitable style complying with the stylistic norms of forms and reports (hence the nominalizations and formalization of the wording), while on the other hand, she also ensures that they are in line with institutional goals and the organisation's central mission (hence the link to the competencies). This example thus 
illustrates that the interviewer performs a range of gate-keeping functions while at the same time allowing the interviewee to contribute to negotiating meaning and to participate in the recording of this discussion by means of the note taking (e.g. by inviting the interviewee to ratify, elaborate or correct her notes).

\section{Dealing with the interviewees' challenges of institutional norms and practices}

The previous section showed an example of an interviewee who, roughly speaking, complied with the institutional norms and the way the interviewer moulds these into a 'fixed' institutional reality through her notes. However, not all employees are so compliant, which poses a challenge to the interviewer, as will be discussed in the following two subsections. Similar behavior was also observed by Nielsen (2009) in a study of middle managers' leadership performance, where the employees did not always collaborate with their middle managers but also at times challenged their managers' attempts at creating meaning and constructing a certain organizational reality.

\section{Successfully dealing with challenges}

The next extract is taken from an interview with an analyst who retired a year after this interview, a point which he has made clear at the beginning of the interview by saying: 'It is the last [interview] anyway so we can go through it quickly'. Furthermore, this interviewee displays his disinterest at numerous occasions throughout the interview. In previous performance appraisal interviews, he has received negative evaluations regarding customer-orientedness. This is the overarching competency of which the current topic under discussion (i.e. patients' issues) is a part.

\section{Example 2 - Interview 2}

Interlocutors discuss how the IE could further improve his involvement with patients' issues (a topic for which the IE has been negatively evaluated in previous interviews).

\begin{tabular}{|c|c|c|}
\hline 1 & IR & Dan hou ich doa vraag 个tien, op welke manier \\
\hline 2 & & blijkt jouw betrokkenheid bij de patiëntenproblematiek $\uparrow$ \\
\hline 3 & & (1.1) \\
\hline 4 & IR & en:::: hoe kuns se die ve- nog verder vergrot[en. \\
\hline 5 & $I E$ & [Dat dat dat \\
\hline 6 & & ken ich dich ( [ \\
\hline 7 & IR & ) 个Wie 个wie waarut bliekt \\
\hline 8 & & ) wie bliekt vuur mich en dan \\
\hline 9 & & has se een concreet vuurbeeld gehuurd (.) \\
\hline 10 & & wat wies du betrokken bes bie de patiëntenproblematiek \\
\hline 11 & & en de kens dan de fertiliteitdingen want dat is denk ik \\
\hline 12 & & toch veur dich het mekkelijk[ste hè \\
\hline 13 & $I E$ & [Des het mekkelijkste. \\
\hline 14 & IR & even concreet, net of ik even neet we \\
\hline
\end{tabular}


((IE describes how he deals with patients and then states that this cannot be improved any further unless he starts 'hugging the patients' as he proposes sarcastically in the next line))

\begin{tabular}{|c|c|c|}
\hline 28 & IE & mot ich se:euh om de hals goan vallen, dat euh \\
\hline 29 & IR & Nee maar goed euh, met patiëntenproblematiek \\
\hline 30 & & hadden we te maken van euh, en dat dees du (.) \\
\hline 31 & & eu:h wee ich (.) euhm dat (.) wen d'er vier IUI's stunt, \\
\hline 32 & & en ze bellen veur een vief[de dats du overleg[s en \\
\hline 33 & $I E$ & [doen ich $[\uparrow J a$ \\
\hline 34 & $I R$ & zegs 'ich goan proberen de viefde nog te doon.' \\
\hline 35 & $I E$ & 个ja ja ${ }^{\circ} a^{\circ}$ \\
\hline 36 & IR & En dat bedoel ich (.) met (.) o- dan bes se betrokken \\
\hline 37 & & bij de patiën[t namelijk. \\
\hline 38 & $I E$ & {$[\mathrm{Mmm}$} \\
\hline 39 & & (3.2) \\
\hline 40 & IR & en das dan auch een concreet voorbeeld (van de) vijfde IUI \\
\hline 41 & $I E$ & Of de zesde of de zevende \\
\hline 42 & IR & Ja,fjafh• @@@@@ \\
\hline 43 & $I E$ & To[en houwen we er acht motten hubben dè zoaterdag, eine \\
\hline 44 & IR & {$[()$} \\
\hline 45 & IE & hou neet gebeld dus dè hadde we neet meer ingepland $\bullet$ hhh \\
\hline 46 & IR & $\downarrow J a$. \\
\hline 47 & & (4.6) \\
\hline 1 & $\mathrm{IR}$ & Then I have question $\uparrow$ ten there, in what way \\
\hline 2 & & does your involvement with the patients' issues show it $\uparrow$ self \\
\hline 3 & & (1.1) \\
\hline 4 & IR & and:::: how could you increase that fu- even furt[her. \\
\hline 5 & IE & [That that that \\
\hline 6 & & I can you ( [ \\
\hline 7 & IR & ) $\uparrow$ How $\uparrow$ how from what does it show \\
\hline 8 & & ) how does it show for me and then \\
\hline 9 & & you have heard a concrete example (.) \\
\hline 10 & & what how you are involved in the patients' issues \\
\hline 11 & & and you can then the fertility things because that is I think \\
\hline 12 & & for you still the eas[iest hey \\
\hline 13 & IE & [That's the easiest. \\
\hline 14 & IR & Yes (.) to just now concretely there, just as if I don't know for a bit \\
\hline 15 & & what you $\mathrm{d}[\mathrm{o}$ \\
\hline 16 & IE & [Yes I don't think that I \\
\hline 17 & & can make that still a lot more concrete there $=$ \\
\hline
\end{tabular}

((IE describes how he deals with patients and then states that this cannot be improved any further unless he starts 'hugging the patients' as he proposes sarcastically in the next line)) I will have to start:erm hugging them, that erm we had to do of erm, and you did that (.) e:rm I know (.) erm that (.) when there are four IUI's, and they call for a fif[th that you confe[ $r$ and 


\begin{tabular}{|c|c|c|}
\hline 35 & $\mathrm{IE}$ & 个yes yes ${ }^{\circ}$ yes $^{\circ}$ \\
\hline 36 & $\mathrm{IR}$ & And that's what I mean (.) with (.) o- then you are involved \\
\hline 37 & & with the patien[t actually. \\
\hline 38 & $\mathrm{IE}$ & {$[\mathrm{Mmm}$} \\
\hline 39 & & (3.2) \\
\hline 40 & $\mathrm{IR}$ & and that's then also a concrete example (of the) fifth IUI \\
\hline 41 & $\mathrm{IE}$ & Or the sixth or the seventh \\
\hline 42 & IR & Yes, fyesf h•@@@@@@ h•h•h•hhh• \\
\hline 43 & $\mathrm{IE}$ & Th[en we should have had eight on Saturday, one \\
\hline 44 & $\mathrm{IR}$ & 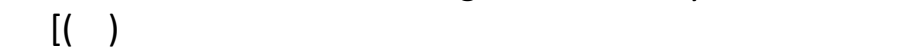 \\
\hline 45 & $\mathrm{IE}$ & did not call so we hadn't planned that anymore $\bullet$ hhh \\
\hline 46 & $\mathrm{IR}$ & $\downarrow$ Yes. \\
\hline 47 & & (4.6) \\
\hline
\end{tabular}

Given the wider contextual elements (e.g. the interviewee's upcoming retirement and his explicitly expressed disinterest in the interview) and the specific contextual elements (e.g. the interviewee's previous negative evaluation on this point), the potentially problematic nature of this topic and its likeliness to elicit challenges by the interviewee is fairly obvious. This is also confirmed in the data, in particular in the interviewer's question design. After she initially asks the question in a neutral way, much in the same way as in example 1, the interviewee starts answering it. However, before his answer starts making sense, since it is initially characterized by reformulations (triple repetition of 'that', line 5), the interviewer overlaps and when she fully gains the floor, she repeats and paraphrases the first question a number of times, and suggests answering it with a concrete example (line 9) from a particular area in which the interviewee is active (namely fertility, line 11). She frames this area as the easiest for the interviewee, because of his specialization, and this is also corroborated by the interviewee. However, in spite of this affirmation, no answer follows, and the interviewer then again encourages him to formulate a concrete response for a lay person (line 1415). Even though the interviewee responds negatively in the subsequent turns ('I don't think that I can make that still a lot more concrete there', lines 16-17 and 'or that I can still improve that', line 19 (omitted here)), he then embarks on a discussion of how he treats the patients. So through the way in which the interviewer designs, repeats and rephrases her question, it is shown that she expects upcoming trouble. This strongly resembles the elaborate questions that Puchta and Potter (1999) studied in the context of focus groups and for which they concluded that these questions "are organized in ways which provide the kinds of answers that focus group moderators require", as such serving, as one of its functions, to guide responses and head off trouble (Puchta and Potter, 1999: 332). So already in the initiation phase of the topic, the interviewer anticipates challenges of institutional norms, and by asking the interviewee to tell her 'just as if I don't know for a bit what you do' (lines 14-15), she implies that there is a positive response to this question, as such projecting a positive and preferred response upon the interviewee (see also Van De Mieroop and Vrolix, 2014). This elaborately (re)formulated question can be interpreted as a leadership activity by the interviewer, since it is an attempt to anticipate challenges and guide the interviewee's response in a direction that will lead to the desired outcome, similar as Puchta and Potter's observations (1999), in this case resulting in an answer that can be institutionalized and 'captured' in the performance appraisal report. 
After having described fairly neutrally how he deals with the patients (omitted here for reasons of length), the interviewee closes this topic with the sarcastic remark that he will have to start hugging (line 28) his patients if he has to further improve his behavior. This clearly implies that he asserts that there is no more room for improvement. He thus clearly challenges the institutional expectation that underlies performance appraisal interviews, namely that staff are expected to continuously improve their performance. This kind of challenging behavior is typical for this particular interview which contains several instances where the interviewee challenges and tries to undermine the interviewer's attempts to come to an answer to the questions which is in line with the institution's expectations (see also example 4 below).

The interviewer responds to these challenges with a negative particle which is oriented towards this sarcastic remark (line 29), and by means of the contrasting conjunction maar ('but') she opposes it to the positive evaluation goed ('good', line 29) that is oriented to the interviewee's preceding description (as will also be clear from the fact that it is retrieved for note taking, as shown in line 62 in example 4 below). The interviewer then continues to re-initiate the topic of patients' issues and embarks on a broad definition (hadden we te maken van, 'we had to do of', line 30), but then breaks off to assert her knowledge of the interviewee's involvement in this. The interviewer thus projects a positive evaluation upon the interviewee which is strongly emphasized because of the repeated nature of these projections, every time followed by a pause (lines 30 and 31). As such, she changes the tone of the conversation from sarcastic to positive and constructive. Ensuring a positive atmosphere and keeping the conversation going are vital for the success of performance appraisal interviews and can be interpreted as leadership activities as they ultimately ensure that the goals of the organization (in this case, the annual appraisal of its members) are being met.

However, after providing some agreeing minimal feedback (lines 33, 35 and 38) the interviewee challenges the interviewer's 'concrete example' (line 40) by claiming experience with even more extreme cases (line 41). This could be read, parallel with the sarcastic extreme case of hugging the patients, as a challenge to the ever increasing demands that the institution poses to its employees. To some extent, the subsequent laughter by the interviewer mitigates this challenge (line 42). However, the interviewee does not join in with this laughter, but instead continues with a very concrete description, as marked by the precise time indication ('Saturday', line 43) and the detailed description of what happened in an even more extreme case ('eight IUI's' ${ }^{\prime 2}$, lines 43 and 45). He thereby not only challenges the institutional goals of ever increasing work pressure but also the interviewer's specialist knowledge of the markedness of particular amounts of IUI's that have to be dealt with in a specific amount of time. The interviewer's affirmative response with a falling intonation (line 46) closes the discussion for now, since in the lengthy pause that follows, the interviewer is taking notes (as the initial line of example 4 shows).

\section{Relatively unsuccessfully dealing with challenges}

We discuss one more example here to show how the interviewer responds to challenges issued by another interviewee who co-ordinates a subsegment of the lab which is specialized in quality-control.

\footnotetext{
${ }^{2}$ IUI stands for intrauterine insemination, which is a fertility treatment.
} 
Example 3 - Interview 3

IE is answering the question about how to further increase her involvement in patients' issues.

\begin{tabular}{|c|c|c|}
\hline 6 & $I E$ & - h Ja doa hou ich biegezatten inderdaad, \\
\hline 7 & & euh euh altied mien best doon veur te zorgen dat \\
\hline 8 & & alles soepel en zoe snel meugelijk verluipt. \\
\hline 9 & & Maar ich heb geen idee wat ich nog (.) <moet doon> of \\
\hline 10 & & ken doon veur dat nog te vergroten op ein [of ander maneer. \\
\hline 11 & $I R$ & [Maar \\
\hline 12 & $I R$ & euh \\
\hline 13 & & (1.6) \\
\hline 14 & IR & Alles alles hè, alles wiest op alles hè. \\
\hline 15 & & Maar specifiek met betrekking tot patiëntenproblematiek. \\
\hline
\end{tabular}

((IE outlines a concrete scenario where she deals with patients' problems))

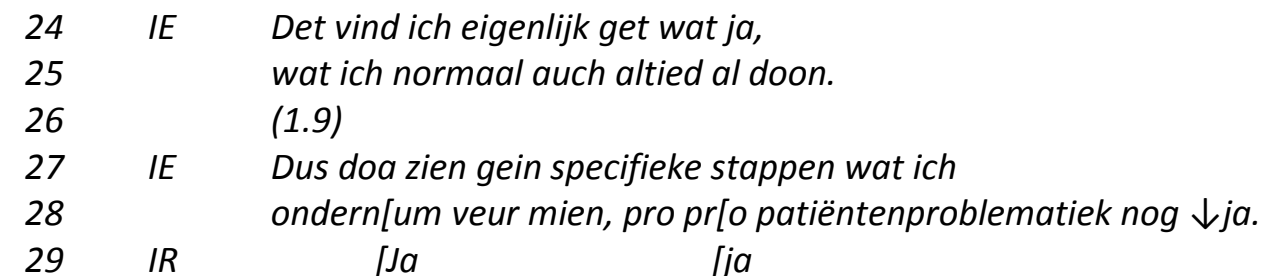

((IE elaborates on the concrete scenario))

$\begin{array}{lll}57 & I E & \begin{array}{l}\text { Dorveur heb ich neet het idee dat ich nog get (.) } \\ 58\end{array} \\ 59 & \text { ja, nog get anders ken doon voor det } \\ 60 & \text { IE } & \text { Nog get meer kens uitbreiden. } \\ 61 & & \text { (.) }\end{array}$
$6 \quad$ IE $\quad \cdot$ Y Yes there I have put indeed,
$7 \quad$ erm erm always do my best to make sure that
8 everything goes smooth and as quickly as possible.
$9 \quad$ But I have no idea what I still (.) <have to do> or
10 can do to increase that further in one way [or another.
11 IR [But
12 IR erm
$13 \quad(1.6)$
14 IR Everything everything hey, everything points to everything hey.
$15 \quad$ But specifically concerning patients' issues.

((IE outlines a concrete scenario where she deals with patients' problems))

24 IE I think that is actually something that yes,

25 what I normally also already do all the time.

$26 \quad$ (1.9)

27 IE So there are no specific steps that I

28 under[take for my, pro pr[o patients' issues still $\downarrow$ yes.

29 IR [Yes [yes

((IE elaborates on the concrete scenario))

57 IE That's why I don't have the idea that I still something (.)

58 yes, can do still something else for that 
$59 \quad$ IR $\quad$ Still extend that more.

60 IE Yes would be able to extend it.

$61 \quad($.

In lines 9-10 the interviewee explicitly states that she does not know how she could further improve her performance related to patients' issues. As elaborated in the previous example, this challenges the institutional norms and expectations of employees' continuous improvement. Moreover, since this is formulated as an obligation (moet doon, 'have to do', line 9), its challenging nature is further emphasized. These discursive means together with the pause and the slower speaking speed contribute to framing it as an institutional order. However, in the next line, she switches to the modality of possibility (ken doon, 'can do' rather than 'have to do', line 10), thus downplaying the initial obligatory tone. The interviewer first responds by overlapping with a contrastive conjunction (line 11) before she hesitates and pauses before eventually uttering a reformulated, vague assertion about the relatedness of things in the organization (line 14) and a subsequent probe for a more specific answer regarding the topic of the question (line 15). This then prompts the interviewee to think about a specific example (following line 15, not shown here) outlining the kinds of activities that she regularly engages in. However, as the interviewee's subsequent turn closing remarks in lines 24-25 show, she is still not convinced that her own example (and the routine activities that she has just described) provide a positive answer since they are typical for her job anyway and do thus not provide an example of how she could further increase her performance. In particular, her use of the Dutch discourse marker 'eigenlijk' (which we have translated as actually here) marks this as "unexpected to the hearer" (van Bergen et al., 2011: 3881). Her summarizing comment in lines 27-28 explicitly frames the preceding turns as a negative response to the second question. In responding to this repeated challenge the interviewer overlaps with a repeated yes (line 29) that functions as a continuer here (Mazeland, 1990) and which prompts the interviewee to provide more of the concrete scenario (not shown here) she mentioned in line 17.

At the end of this episode the interviewee still resists the institutional assumption that her performance can be further improved, as the reformulated topic closing statement of lines 57-58 indicates, which is formulated as a summary in which all the preceding talk is framed as an account for this answer (hence the initial dorveur, 'that's why', line 57). The interviewer responds to this by vaguely asserting to extend that more (line 59), albeit unclear whether this is either a suggestion for improvement of the interviewee's professional behavior, which would hence be in line with the instititutional goal of continuous improvement, or a continuation of the interviewee's turn, thus agreeing with her negative response. In spite of this vagueness, this seems to satisfy the interviewee as her final response (line 60) indicates.

This example is thus a good illustration of a rather unsuccessful attempt to steer the interviewee into the direction of an institutionally acceptable answer. This interviewee is very straightforward in her response, since each of the anecdotes that she provides (which have been deleted here for reasons of space) are framed as accounts that back up this negative response to the question for improvement regarding patients' issue. She thus leaves no room for the interviewer to negotiate this answer and mould it into a positive response that would have been in line with the institutional goals. 
As we have demonstrated in the analyses of Examples 2 and 3, there are a number of techniques through which the interviewer attempts to gain the interviewee's compliance, including the design of the question (Example 2), and the negotiation of the topic in the course of the interaction (Examples 2 and 3). The ways in which this institutional reality is eventually recorded in the report, are of course essential for the way in which this reality is formalized and 'captured'. This will be discussed in the following section.

\section{Institutionalizing these challenges}

This section elaborates on Examples 2 and 3 and examines how these challenges are dealt with in the interviewer's note taking. We discuss how the interviewer either does (Example 4) or does not (Example 5) encourage the interviewee to ratify the institutionalization of the interviewee's words.

\section{Encouraging the interviewee to ratify the institutionalization of the interviewee's words}

Example 4 - Interview 2

This excerpt and example 2 come from the same interview It occurred right after the sequence shown previously.

\begin{tabular}{|c|c|c|}
\hline 48 & IR & $\downarrow J o a, i$ i hem dus dat de klantgerichtheid is good. \\
\hline 49 & & $>$ Das neet meer voor verbetering vatbaar dat punt vervalt.< \\
\hline 50 & & Ich hou even op[geschreven \\
\hline 51 & $I E$ & [Ja, MOrgen misschien wel maar \\
\hline 52 & & euh ja dat euh dat i[s \\
\hline 53 & $I R$ & [NEE ich hou opgeschreven, \\
\hline
\end{tabular}

((7 lines omitted summarizing the part of the interaction immediately preceding extract $2 A)$ )

61 met betrekking tot de patiëntenproblematiek

62 eu:: $\mathrm{h}$ ja persoonlijk benaderen van de klant (.)

63 en vervolgens bijvoorbeeld bij een vroag vijfde zesde of

$64 \quad m$ [eerdere IUI's bekijken hoe we dit kunnen oplossen.

65 IE $\quad[\mathrm{Mmm}$.

66 IE Uhu.

67 IR Dan is dat, dan ben ich fehrig met klantgerichtheid.

$48 \quad$ IR $\quad \downarrow$ Yes, so II have that the customer orientedness is good.

$49 \quad>$ That is not open to improvement anymore that point is gone.<

$50 \quad$ I have just writ[ten down

51 IE [Yes, TOmorrow maybe yes but

52 erm yes that erm that i[s

53 IR [NO I have written down,

((7 lines omitted summarizing a previous part of the interaction))

61 concerning the patients' issues

62 e::rm yes personally approaching the customer (.)

63 and subsequently for example at a request fifth sixth or

$64 \mathrm{~m}$ [ore IUI's looking at how we can solve this.

$65 \mathrm{IE} \quad[\mathrm{Mmm}$. 
67 IR Then is that, then I am ready with customer orientedness.

The interviewee starts by reading out a general positive evaluation from her notes (line 48) by means of a rush through which typically enables the speaker to maintain floor holding rights (Schegloff, 1981). She thereby explicitly links this to the interviewee's negative evaluation in previous performance appraisal interviews (line 49). However, rather than ratifying this positive evaluation, the interviewee overlaps with the interviewer and in a loud voice challenges her by vaguely asserting that his behaviour may be open to improvement again in the future (line 51). This challenge contains the Dutch particle wel (translated here as 'yes'), which marks "a denial of an implicit or explicit previous denial" (Hogeweg, 2009: 522), which underlines the interviewee's assertiveness. With this challenging comment, the interviewee also implicitly questions the purpose and usefulness of performance appraisal interviews as an institutional practice since he explicitly suggests that his behavior may change considerably for the worse the next day. Given the fact that the interviewer's evaluation of the interviewee's behavior was positive, this challenge may seem a bit odd, but it can be related to the rather negative and disinterested tone in the rest of the interview (not shown here, but see also Example 2) and the contextual factor that the interviewee is close to his retirement, which makes evaluations to encourage employees' progress relatively useless.

The interviewer deals with this challenge by overlapping the interviewee's words with a loudly voiced negative particle (nee, 'no', line 53), which can be oriented to as an interruption (Hutchby, 1992). As such, the interviewer takes back the floor and stops the topic transition that the interviewee initiated in the preceding lines. So instead of going along with the interviewee, the interviewer repeats the preliminary remark of line 50 thereby framing the upcoming talk as the reading out loud of her notes. This is the start of a lengthy, uninterrupted turn consisting of 11 lines (of which 7 lines are deleted here for reasons of space). When she comes to the topic that was under discussion in Example 2, she uses a style that is highly institutionalized, as is reflected in for example, the nominalized verbs (benaderen, 'approaching', line 62, bekijken, looking', line 64), the distanced reference to the patients as de klant ('the customer', line 62), and the elliptical style (line 63). Interestingly, her summary integrates both the topic that was previously initiated by the interviewee himself about dealing with patients, and another topic that the interviewer has brought up regarding the number of IUI's the interviewee can handle per day (see Example 2). The interviewee provides agreeing minimal feedback to the interviewer's summary (lines 65 and 66) after which the interviewer explicitly closes the overarching topic and moves on to the next topic on the agenda (line 67).

As in the previous examples, in this interview the interviewer also displays a clear orientation towards arriving at an institutionalisable answer to the two questions on the report form. On the one hand, she does this by interrupting the interviewee when he challenges the usefulness of the performance appraisal interview. On the other hand, by reading out her notes and leaving room for acknowledgment of these by the interviewee, the answer is collaboratively constructed, albeit in a minimal way since the only contribution of the interviewee consists of minimal alignment (lines 6566) with the interviewer's version of reality, which gets written down and thus 'fixed' as the organizational reality (Taylor, 2011). So although the interviewer clearly takes on a leadership role in these activities, she also involves the interviewee in the processes of constructing meaning. Thus, in 
spite of the interviewee's repeated challenges, the interviewer manages to steer the discussion towards a mutually agreed and institutionalisable answer that captures (organizational) reality.

\section{Not encouraging the interviewee to ratify the institutionalization of the interviewee's words}

Example 5 - Interview 3

After a lengthy discussion between IE and IR, the latter summarizes what they have spoken about. This extract and example 3 come from the same interview.

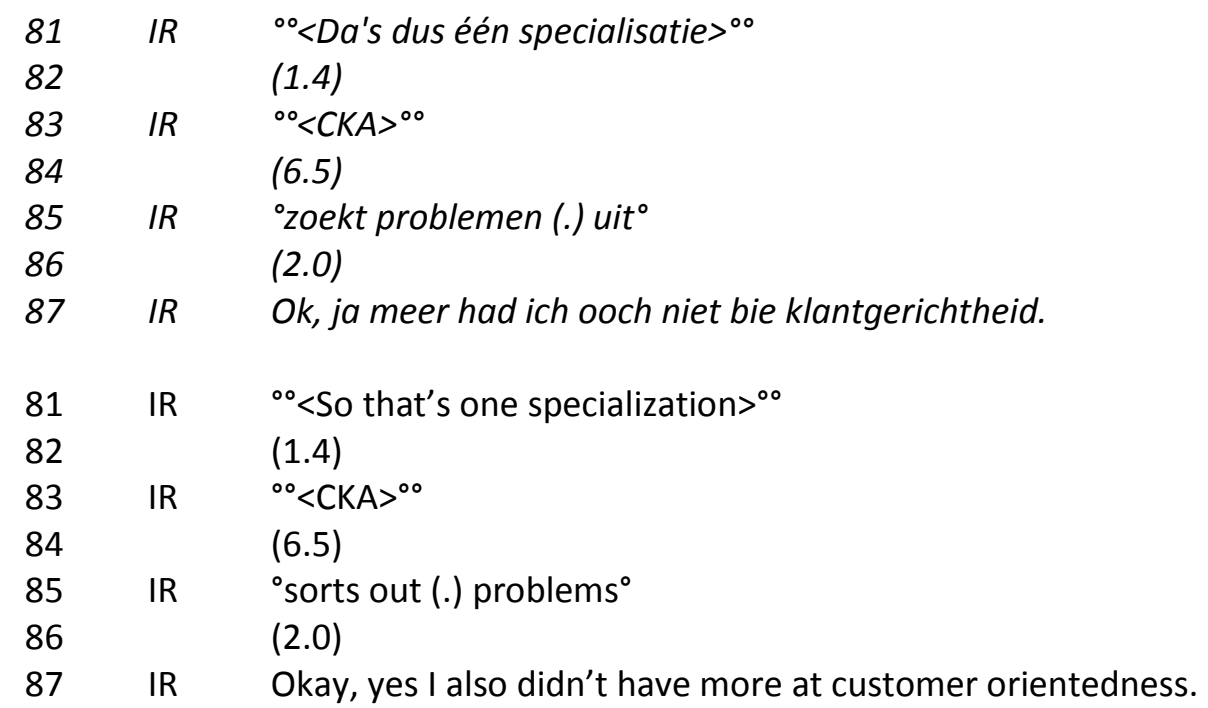

In this excerpt the interviewer provides a very partial rendering of her notes, without framing them as such, as was the case in Examples 1 and 4. What is interesting about this example is the observation that the interviewee does not interrupt the interviewer at all during this process of summarizing, rephrasing and noting down the outcomes of their previous discussion in institutional terms. In short, the interviewer is doing formulation, thus fixing "past and present organizational reality" (Clifton, 2006: 210), which is typically also a place at which the other interlocutors can voice either their agreement or disagreement (Clifton, 2006), as we have also discussed previously (see Examples 1 and 4). In this case however, the interviewee takes a relatively passive role and steps back as the interviewer performs her tasks. There is also no sign of an invitation to the interviewee to make adjustments or to acknowledge the formulation of her previous contributions into an institutionalized answer - not even during the pauses ${ }^{3}$ which follow the utterances of the interviewer (e.g. line 85). When comparing this with the first interview, in which the interviewer at a similar point in the interaction used a tag hè ('hey', example 1: line 28) with rising intonation which can be interpreted as an invitation for the interviewee to take the floor, we see an interactionally less inviting 'format' here. This is especially so because of the specific form of the interviewer's contributions, in comparison to those of, for instance, example 4. In this example, the interviewer's words are brief and the sentences elliptic, which is quite indicative of their 'closed' nature. They are

\footnotetext{
${ }^{3}$ This cannot be stated with certainty though, since for example the interviewer could have looked at the interviewee during the pauses and this eye gaze could be interpreted as an invitation to contribute to this process of doing formulation. Since we do not have any video data, we thus have to be careful when drawing conclusions here.
} 
also pronounced very quietly, contrary to the notes that are read out loud in examples 1 and 4 . So in comparison to the latter examples, we could conclude that the interviewer is not particularly encouraging ${ }^{4}$ the interviewee to ratify this process of 'fixing' the answer in her notes. The interviewer then closes the topic in line 87 and shifts to another topic. She thereby enacts a leadership role and performs gate-keeping functions, namely to ensure the report is filled in correctly with appropriate (i.e. institutionalized) terminology, as is reflected in for example her use of jargon (e.g. line 83). Finally, the form of the interviewer's contributions (namely a few elliptic constructions which are softly mumbled) and the interviewer's interactional behavior in this extract blur the way in which the interviewee's negative response is 'captured' and institutionalized, since, given the lack of an explicit report on her notes at the end, it remains unclear whether the negative response was actually incorporated in the notes or the final report. ${ }^{5}$

\section{Discussion}

It was the aim of this paper to explore some of the processes through which leadership is performed in an institutional context other than the well-researched business meeting. To achieve this, we have looked at performance appraisal interviews, which are becoming increasingly relevant in many institutional contexts. Our particular focus was on identifying and describing some of the discursive resources that interlocutors draw on when enacting the gate-keeping activities of meaning construction and obtaining an institutionalisable answer in the course of the interaction, as well as when this interaction is 'captured' in the interviewer's notes, as such taking the first step to 'fixing' organizational reality.

Our in-depth analyses of five excerpts from three performance appraisal interviews have shown that these activities involve relatively long and often challenging discussions between the interviewer and the interviewees. More specifically, in order to agree on and eventually write down an answer to the various questions that reflects institutional practices, expectations and values, interlocutors had to engage in collaborative negotiations and constructions of meaning. The main gate-keeping strategies involved in enacting these leadership activities include (1) rephrasing the interviewees' words in more institutional terms relating them more specifically to the competencies of the organization (Example 1), (2) dealing with the interviewee's challenges of institutional norms and practices (Examples 2 and 3), and (3) institutionalizing these challenges (e.g. with different degrees of encouragement (Example 4 versus 5) to the interviewees to ratify the institutionalization of their words). An analysis of the specific processes involved in these activities revealed interesting insights into the complexities of how leadership is actually done on the micro-level of interaction.

What was particularly interesting about our observations was the fact that both interlocutors contributed to these leadership activities. More specifically, although the interviewer played a central role in most of these processes (e.g. by attempting to steer the on-going meaning construction towards obtaining an institutionalisable answer), in order for these leadership

\footnotetext{
${ }^{4}$ At least linguistically, see previous footnote.

${ }^{5}$ Unfortunately, for reasons of confidentiality, no access to the reports was granted.
} 
behaviours to be successful (i.e. to actually result in an institutionalisable answer that gets written down as the first step of solidifying conversation into texts (Koschmann, 2013)), this process also requires the collaboration of the interviewee who needs to cooperate in the negotiation of meaning and the construction of an institutionalisable answer. The complexities of this collaboration were particularly obvious in those instances where the interviewee challenged or resisted the specific norms and expectations that underlie particular questions. Through actively participating in the meaning construction in these instances both interlocutors crucially contributed (1) to the discursive creation of an organizational reality that reflects and reinforces institutional expectations, practices and norms and (2) to the 'fixing' of this institutionalisable reality in written form, which will subsequently be the basis of a report in which the interactional complexity will be mostly erased by means of a process that Taylor calls "imbrication" (2011: 1285).

These observations are in line with recent trends in leadership research which has pointed out that leadership is a collaborative undertaking that involves several people (e.g. Day et al., 2004; Gronn, 2002; Heenan and Bennis, 1999; Jackson and Parry, 2008). As our analyses have shown, taking a discourse analytical approach to the study of leadership, i.e. by focusing on the specific strategies through which leadership is enacted, provides a useful approach to investigate such collaborative conceptualisations of leadership. In particular, it enables researchers to move away from looking at individuals towards a focus on the specific processes and strategies through which the various leadership activities are actually preformed - necessarily conjointly. The various processes involved in the negotiation of meaning and the co-construction of organizational realities in the performance appraisal interviews that we have discussed in this paper have clearly illustrated that leadership is most productively conceptualized as an activity in which (several) people participate. Through this collaboration among interlocutors (which may or may not be harmonious (see also Schnurr and Chan, 2011)), organizational goals are negotiated and specific versions of organizational reality are being created and can then be subsequently "imbricated" (Taylor, 2011) and 'fixed" in written form. Our in-depth analyses of some of the gate-keeping strategies through which leadership is enacted in performance appraisal interviews thus also provide further support for calls to re-conceptualise leadership as a collaborative process (Day et al., 2004; Gronn, 2002) that should be regarded from a multimodal perspective. Future studies will have to further explore the applicability of such a conceptualization of leadership, ideally in organizational contexts other than business meetings. It is about time we move beyond the known realms of business meetings and look at other, equally relevant sites of leadership performance if we want to better understand the complex processes involved in doing leadership.

\section{References}

Angouri, Jo, Marra, Meredith, 2011. 'OK one last thing for today then': constructing identities in coporate meeting talk. In: Angouri, J., Marra, M. (Eds.), Constructing identities at work. Palgrave Macmillan, Houndmills, pp. 85-100.

Antaki, Charles, 2002. An introductory tutorial in conversation analysis. Available at: http://wwwstaff.lboro.ac.uk/ssca1/notation.htm. Last accessed on 3 March 2014. 
Asmuß, Birte, 2008. Performance appraisal interviews: Preference organization in assessment sequences. Journal of Business Communication 45 (4), 408-429.

Asmuß, Birte, 2009. Meeting talk. An introduction. Journal of Business Communication 46 (1), 3-22. Baxter, Judith, 2010. The Language of Female Leadership. Palgrave Macmillan, London.

Benoit-Barné, Chantal, Cooren, François 2009. The accomplishment of authority through presentification: How authority is distributed among and negotiated by organizational members. Management Communication Quarterly 23 (1), 5-31.

Boden, Deirdre, 1994. The Business of Talk; Organizations in Action. Cambridge, Polity Press.

Choi, Seongsook, Schnurr, Stephanie, 2014. Exploring distributed leadership: Solving disagreements and negotiating consensus in a 'leaderless' team. Discourse Studies 16 (1), 3-24.

Clifton, Jonathan, 2006. A conversation analytical approach to business communication. Journal of Business Communication 43 (3), 202-229.

Clifton, Jonathan, 2012a. Conversation analysis in dialogue with stocks of interactional knowledge: Facework and appraisal interviews. Journal of Business Communication 49 (4), 283-311.

Clifton, Jonathan, 2012b. A discursive approach to leadership. Doing assessments and managing organizational meanings. Journal of Business Communication 49 (2), 148-168.

Day, David, Gronn, Peter, Salas, Eduardo, 2004. Leadership capacity in teams. The Leadership Quarterly 15 (6), 857-880.

Enderle, Georges, 1987. Some perspectives of managerial ethical leadership. Journal of Business Ethics 6 657-663.

Fairhurst, Gail T., 2007. Discursive Leadership. In Conversation with Leadership Psychology. Sage, London.

Gronn, Peter, 2002. Distributed leadership as a unit of analysis. The Leadership Quarterly 13 (4), $423-$ 451.

Heenan, David, Bennis, Warren, 1999. Co-Leaders. The Power of Great Partnerships. John Wiley \& Sons, New York.

Heifertz, Ronald, 1998. Values in leadership. In: Robinson Hickman, G. (Ed.), Leading Organizations. Perspectives for a New Era. Sage, London, pp. 343-356.

Hogeweg, Lotte, 2009. The meaning and interpretation of the Dutch particle wel. Journal of Pragmatics 41 (3), 519-539.

Holmes, Janet, 2000. Politeness, power and provocation: how humour functions in the workplace. Discourse Studies 2 (2) 159-185.

Holmes, Janet, 2005. Leadership talk: How do leaders 'do mentoring', and is gender relevant? Journal of Pragmatics 37 (11), 1779-1800.

Holmes, Janet, 2006. Gendered Talk at Work. Blackwell, Oxford.

Holmes, Janet, 2007. Monitoring organisational boundaries: Diverse discourse strategies used in gatekeeping. Journal of Pragmatics 39 (11), 1993-2016.

Holmes, Janet, Marra, Meredith, Vine, Bernadette, 2011. Leadership, Discourse and Ethnicity. Oxford University Press, Oxford.

Holmes, Janet, Stubbe, Maria, 2003. Power and Politeness in the Workplace. London, Longman.

Hosking, Dian Marie, 1997. Organizing, leadership, and skilful process. In: Grint, K. (Ed.), Leadership. Classical, Contemporary, and Critical Approaches. Oxford University Press, Oxford, pp. 293318.

Hutchby, lan, 1992. Confrontation Talk: Arguments, Asymmetries, and Power on Talk Radio. Lawrence Erlbaum Associates, Mahwah, New Jersey. 
Jackson, Brad, Parry, Ken, 2008. A Very Short, Fairly Interesting and Reasonably Cheap Book About Studying Leadership. Sage, Los Angeles.

Koschmann, Matthew A. , 2013. The communicative constitution of collective identity in interorganizational collaboration. Management Communication Quarterly 27 (1), 61-89.

Marra, Meredith, Schnurr, Stephanie, Holmes, Janet, 2006. Effective leadership in New Zealand workplaces: Balancing gender and role. In: Baxter, J. (Ed.), Speaking Out: The Female Voice in Public Contexts. Palgrave, Basingstoke, pp. 240-260.

Mazeland, Harrie, 1990. "Yes","no", and "mhm": variations in acknowledgment choices. In: Conein, B., de Fornel, M., Quéré, L. (Eds.), Les formes de la conversation. Réseaux.Communication Technologie - Société, Issy les Moulineaux, pp. 251-282.

Nielsen, Mie Fem $\varnothing$, 2009. Interpretative management in business meetings. Understanding managers' interactional strategies through conversation analysis. Journal of Business Communication 46 (1), 23-56.

Northouse, Peter, 1997. Leadership. Theory and Practice. Sage, London.

Puchta, Claudia, Potter, Jonathan, 1999. Asking elaborate questions: Focus groups and the management of spontaneity. Journal of Sociolinguistics 3 (3), 314-335.

Rogerson-Revell, Pamela, 2011. Chairing international business meetings: investigating humour and leadership style in the workplace. In: Angouri, J., Marra, M. (Eds.), Constructing identities at work. Palgrave Macmillan, Houndmills, pp. 61-84.

Schegloff, Emanuel A., 1981. Discourse as an interactional achievement: some uses of 'uh huh' and other things that come between sentences. In: Tannen, D. (Ed.), Analyzing Discourse: Text and Talk; Georgetown University Roundtable on Languages and Linguistics. Georgetown University Press, Washington D.C., pp. 71-91.

Schnurr, Stephanie, 2009a. Constructing leader identities through teasing at work. Journal of Pragmatics 41 (6), 1125-1138.

Schnurr, Stephanie, 2009b. Leadership Discourse at Work; Interactions of Humour, Gender and Workplace Culture. Palgrave Macmillan, Houndmills.

Schnurr, Stephanie, Chan, Angela, 2009. Leadership discourse and politeness at work. A cross cultural case study of New Zealand and Hong Kong. Journal of Politeness Research 5 (2), 131-157.

Schnurr, Stephanie, Chan, Angela, 2011. Exploring another side of co-leadership: Negotiating professional identities through face-work in disagreements. Language in Society 40 (2), 187 210.

Schnurr, Stephanie, Zayts, Olga, 2011. Be(com)ing a leader: a case study of co-constructing professional identities at work. In: Angouri, J., Marra, M. (Eds.), Constructing identities at work. Palgrave Macmillan, Houndmills, pp. 40-60.

Smircich, Linda, Morgan, Gareth 1982. Leadership: The management of meaning. The Journal of Applied Behavioral Science 18 (3), 257-273.

Svennevig, Jan, 2011. Leadership style in managers' feedback in meetings. In: Angouri, J., Marra, M. (Eds.), Constructing identities at work. Palgrave Macmillan, Houndmills, pp. 17-39.

Svennevig, Jan, 2012. Interaction in workplace meetings. Discourse Studies 14 (1), 3-10.

Taylor, James R., 2011. Organization as an (imbricated) configuring of transactions. Organization Studies 32 (9), 1273-1294.

Tourish, Dennis, Jackson, Brad 2008. Special Issue on Communication and Leadership. Leadership 4 (3). 
van Bergen, Geertje , van Gijn, Rik, Hogeweg, Lotte, Lestrade, Sander, 2011. Discourse marking and the subtle art of mind-reading: The case of Dutch eigenlijk. Journal of Pragmatics 43 (15), 3877-3892.

Van De Mieroop, Dorien, Vrolix, Eveline, 2014. A discourse analytical perspective on the professionalization of the performance appraisal interview. International Journal of Business Communication 51 (2), 159-182.

Yukl, Gary, 2002. Leadership in Organizations (5th edition). Prentice Hall, Upper Saddle River, New Jersey.

Appendix: transcription symbols (based on and taken from Antaki, 2002)

*** INSERT TABLE 1 HERE 